\title{
Conflict and Migration: The Case of Somali Refugees in Northeastern Kenya
}

\author{
Asfaw Kumssa • James Herbert Williams • John F. Jones • \\ Eric A. Des Marais
}

Published online: 27 March 2014

(C) Springer International Publishing 2014

\begin{abstract}
The Dadaab refugee camp was established in 1991 to accommodate Somali refugees fleeing the ongoing violence, environmental and social problems caused by civil war, famine, and drought. The camp is located in Garissa County in the Northeastern region of Kenya. Recent data indicate that the current population of Dadaab camp (463, 422 ) is more than five times the camp's recommended initial capacity of 90,000 people. This influx of refugees into Northeastern Kenya has stressed local resources within the region and requires careful negotiation between the host community residents and refugees. This study analyses this challenging situation through a human security lens, which seeks to encompass the social, political, economic, cultural, and environmental conditions necessary to support sustainable human well-being. The study also identifies the human security challenges facing the refugees and examines the factors influencing conflict between the host community residents and the refugees. Programmatic suggestions for sustainable solutions that empower both the host community residents and the refugees are discussed.
\end{abstract}

Keywords Northeastern Kenya · Somali refugees · Dadaab refugee camp · Conflict · Human security

\section{J. F. Jones is now deceased.}

The views expressed here are the authors' own and not necessarily those of the United Nations Centre for Regional Development. Portions of this article are based on a presentation given at the Global Health and Well-being: The Social Work Response Conference in New York, NY, June, 2013.

\section{A. Kumssa}

United Nations Centre for Regional Development, UN Girgiri Block

A-121, P. O. Box 30218, Nairobi, Kenya

J. H. Williams $(\bowtie) \cdot J$. F. Jones $\cdot$ E. A. Des Marais

Graduate School of Social Work, University of Denver, 2148 South

High St, Denver, CO 80208, USA

e-mail: james.herbert@du.edu
While forced displacement is often linked to a single proximate cause such as a war or natural disaster, the reality is that it occurs within a much broader context involving issues such as historical struggles between racial and ethnic groups, access to natural resources and livelihoods, environmental change or degradation, and political dynamics at local, state, and international levels. While there has been some development of a structure of international norms through the Universal Declaration of Human Rights and the United Nations Convention Relating to the Status of Refugees, the complex overlapping of issues imply that each situation has its unique set of issues and concerns that must be addressed. The Somali refugees in Northeastern Kenya are one case in point.

There are presently over one million registered Somali refugees throughout East Africa with more than $50 \%$ of these refugees being located in Kenya. This influx of refugees has stressed local resources within Kenya and requires careful negotiation between host community residents and refugees. This study analyzes these difficulties through a human security lens. This lens seeks to encompass the social, political, economic, cultural, and environmental conditions necessary for sustainable human and environmental well-being. This study analyzes both primary and secondary data to investigate this global concern.

An initial review of the historical antecedents underpinning the movement of Somali throughout the horn of Eastern Africa is provided. This historical review is followed with an overview of the human security challenges facing these refugees. This study conducts an analysis of the various social, economic, political, and environmental factors influencing conflicts between the host community residents and the refugees. The study concludes with programmatic suggestions for sustainable solutions that empower residents in both the host and refugee communities.

\section{Historical Context}

Throughout the Cold War, the United States and the Soviet Union competed for hegemony over resource-rich Africa 
(Loescher and Milner 2005). Their efforts to destabilize regimes included the provision of military training and weapons to various organizations. These proxy wars exacerbated forced migration throughout Africa (Loescher and Milner 2005). In the meantime, Kenya's porous borders along with its policy of free and open movement for refugees set the stage for an inflow of migrants (Campbell, Crisp and Kiragu 2011). Starting first with the arrival of Ugandan refugees in the 1970s and eventually followed by an influx of all of its surrounding neighbors (i.e., Tanzania, Sudan, Ethiopia, and Somalia). This influx of refugees started to overwhelm the resources of Kenya (Campbell, Crisp and Kiragu 2011).

With the collapse of the Soviet Union and the end of the Cold War, international focus and resources shifted from Africa to newly liberated Eastern Europe (Loescher and Milner 2005). In the meantime, regimes collapsed - as in the case of Somalia - and the situation in Africa became even more chaotic. This precipitated another massive movement of Ethiopian, Somali, and Sudanese refugees into Kenya (Loescher and Milner 2005).

Largely, it was understood that these new refugees were temporarily fleeing; and once their original homes stabilized, they would return. Since Kenya also had concerns about its own national security, it was decided that special camps be built to house these refugees, keep them safe, and help with their repatriation (Campbell, Crisp and Kiragu 2011). These camps were under the auspices of the United Nations High Commissioner for Refugees (UNHCR) and were intended to be a well-organized attempt to manage migration with the goals of providing basic assistance and supporting their eventual return (Campbell, Crisp and Kiragu 2011). However, many refugees and asylum seekers instead wanted to migrate permanently and viewed Nairobi as a better option (Campbell, Crisp and Kiragu 2011).

The Somali civil war and subsequent political instability and the severe droughts in the region forced a large number of Somalis to flee to neighboring countries, primarily Kenya. The majority of the Somali refugees are housed at the Dadaab refugee camp located in Northeastern Kenya. The camp is located $100 \mathrm{~km}$ from the Kenya -Somali border. The first Dadaab camp opened in the early nineties with a capacity of approximately 90,000 Somali refugees.

Over the years, the camp has been expanded to accommodate an increasing number of Somalis fleeing the ongoing violence, environmental, and social problems caused by drought and famine. Dadaab is now the largest refugee camp in the world. Currently, there are approximately 465,146 refugees being housed in Dadaab. Somalis comprise the majority of the refugees in Dadaab, although the population also includes refugees from other African countries (e.g., Democratic Republic of the Congo, Ethiopia, Eritrea, and South Sudan). Dadaab is divided into five camps, namely Dagahaley, Hagadera, Ifo, Ifo-2, and Kambioos. In addition to providing food and shelter, the refugees receive other humanitarian assistance provided by international aid agencies and other nongovernmental organizations (NGOs). These services are inadequate to improve the overall socioeconomic conditions and well-being of the refugees.

It is important to design and implement projects and programs that will engage, promote, and support self-reliance with an outcome of improving refugees' sustainable livelihoods (Kumssa and Jones 2014; Kumssa, Jones, and Williams 2009). These approaches will address the problem of wasted human capacity and deprivation of human dignity (Abdi 2005). Since it is uncertain when these refugees will return to their country of origin, short-term humanitarian assistance should be complemented with a long-term integrated development policy approach.

Mr. Hassan Sheikh Mohamud was elected as President of Somalia in September 2012, and a national government was put into place. The election and new government has increased optimism of potential peace and stability in a country that has not had a proper government since 1991 when its military dictator, Siad Barre, was overthrown in a coup. Another encouraging development in Somalia is that AlShabaab, a terrorist militia group, has largely been driven from Mogadishu, the capital city, and from some parts of the country with the help of international armed forces under the umbrella of the African Union (AU). Although the situation has improved remarkably, Al-shabaab continues to pose a major threat to the peace and security in Somalia and neighboring countries. This is evident by the recent (2013) terrorist attack on a mall in Nairobi that claimed the lives of innocent people. In the interim, the nascent government and a weak national army have limited capacity to restore peace and stability or uniting the country. Other challenge is how to bring about peace and social cohesion among the influential rival Somali clans (Menkaus 2012). Consequently, the political and economic landscape of the country remains precarious, and political and environmental refugees continue to cross the border into Kenya creating unstable political, social, and environmental conditions.

Another political development emerged in 2012 when the Government of Kenya came up with a policy that all refugees and asylum seekers residing in urban areas would be moved to the refugee camps. Somali refugees living in urban areas such as Nairobi were advised to report to Dadaab refugee camp (Daily Nation 2012). Rising security problems linked to terrorist groups that had infiltrated the refugee community in urban areas were the impetus for this policy. It is estimated that many Somalis - including Al-Shabaab members - have taken advantage of corruption in Kenya to secure Kenyan identification cards (Menkaus 2012). Several bomb explosions and killings of innocent Kenyans that have been linked to AlShabaab have forced the Government to take the drastic measure of moving all urban refugees to designated refugee 
camps. However, this policy has been challenged by human rights groups, who contend that the policy violates refugees' right to free movement and is tantamount to unlawful forced eviction (Human Rights 2013). Some rights groups also argue that this plan will outstretch the capacity of the camps, which are overcrowded and congested, and hence limiting the refugees' access to adequate food, housing, health, and other facilities. In conclusion, this policy was never enforced nor implemented.

Since new arrivals often cannot be accommodated in the camps, they have settled around the camp where they live in makeshift abodes. The ever increasing refugee population in the area will continue to exert pressure on the shrinking economic opportunities near and around the camp, causing tension and conflict between the refugees and the host community. Given the fact that pastoralism is the main source of income, competition over control and access to natural resources such as pasture and water exacerbates violence among pastoralist communities. Yet, these resources are not only scarce, but are increasingly under environmental pressure (Kumssa and Jones, 2014; Kumssa, Jones and Williams 2009).

Using primary and secondary data, this paper (1) examines the human security challenges of refugees; (2) examines the environmental impact of the refugees on the surrounding areas and the conflict that arises between refugees and the host community due to environmental degradation; and (3) identifies and addresses new skills required for alternative livelihood creation and conflict prevention aimed at empowering both the refugees and the host community, and enhancing their livelihood and selfreliance, as well as bringing sustainable peace and development.

The paper also contends that the dynamics of the relationship between the refugees and the host community are best understood within the framework of a human security framework that encompasses both conflict and the development aspect of peace and sustainable development. The concept of human security incorporates the creation of social, political, economic, environmental, and cultural conditions necessary for survival, livelihood, and dignity of individual and communities. Within the framework of human security, this paper discusses areas of conflict between the Somali refugees and the host community and how these factors impact refugees' safety. It also proposes policies on how to bring about sustainable peace between the two communities.

The paper contends that conflict between the host community residents and refugees is mainly triggered by the competition over scarce resources rather than by ethnic animosity since both the refugees and the host community are predominately Somalis and share the same religion and cultural background. Therefore, a policy direction to address conflict should focus on capacity building and sensitization programs aimed at improving the knowledge and skills of the host community residents and the refugees. This policy should focus on conflict prevention, management, and peace building techniques, as well as building their capacity in new skills for alternative livelihood creation and sustainable resource management.

Methodology

To support the analysis of the human security and conflict issues in the Dadaab refugee camp and surroundings, the study uses both primary and secondary data. The research design for this study used both qualitative and quantitative methodologies to address human security and conflict issues at the refugee camp in Dadaab. Like several evaluation projects, the study triangulated documentation, interviews/ surveys, and observation. A literature review and desk study was conducted by examining relevant books, articles, reports, and other documents published on the subject of refugees and the host community residents in Dadaab. Primary data was collected in 2012 from local residents in Northeastern Kenya using focus groups and administering face-to-face interviews to refugees and host community representatives. Focus group data allowed for clarification of complex and sensitive issues which enabled researchers to probe and verify confusing questions and issues. The methodology involved the administration of questionnaires to a sample of randomly selected respondents from host community residents and refugees. Completed questionnaires were collected from 177 respondents. Fifty-four percent of the sample was male with $46 \%$ being female. The survey questions focused on the socioeconomic conditions of the residents of host community and the refugees. The questions covered the following topics: shelter; livelihood and income; school and the capacity of teachers; conflict prevention and peace building; fuel and an alternative source of energy; and water, sanitation, and hygiene (WASH). The survey data were analyzed using Statistical Package for Social Sciences (SPSS).

During the field visit, researchers also had an opportunity to collect information through observation of the human security situation of the refugees and the host community residents. These observations focused on livelihood conditions, settlement patterns, landscape, agro-economy, and deterioration caused by recent drought and ongoing environmental degradation. Researchers also observed measures that had been undertaken and currently underway by various international humanitarian organizations and NGOs to alleviate the condition of the refugees.

\section{Human Security for Displaced People}

Human security is defined as a process of intervention aimed at protecting the vital core of all human lives in ways that enhance human freedoms and human fulfillment through the protection of civil rights and the provision of basic human needs. This definition is based on that of the Commission on Human Security, but with the added explicit reference to civil 
rights and basic human needs. The phrase "human security" is intended to capture today's environment with a new nuance and tone. The term is especially linked to the plight of the world's absolutely poor as well as the tragedy of refugees and internally displaced people, but the concept has implications for all vulnerable populations (Hasegawa 2007). Whether in the developed industrial north or in the global south where entire populations live in want, there is a common fear of the consequences of extreme poverty, especially the associated violence.

It encompasses the idea of liberty, with a specific emphasis on civil rights and sustainable development. The term covers both conflict resolution and the socioeconomic aspects of human progress. In the past, security generally meant the defense of nation-states and their territory from external aggression and protecting national borders by force of arms. This is, however, a narrow definition of the concept, and the current understanding of security go beyond national security issues to focus on the welfare and security of individuals and communities such as refugees and the internally displaced people. The human security approach is an essential means for addressing critical and pervasive threats to people's lives, livelihoods, and dignity, which compromise peace and sustainable development (Hasegawa 2007). This approach identifies threats to vulnerable groups and capacity gaps in implementing alternative and sustainable development programs to improve both the livelihoods of the refugees and those of the host community. This approach entails identifying the following:

- The most critical and pervasive threats to both refugees and host community residents;

- Communities and groups most vulnerable in view of these threats;
- Manifestation of these threats on different domains of human security, whether political, economic, communal, health, environment, etc.

- The interconnected insecurities that arise as a consequence of these threats; and

- The protection and empowerment strategies needed in responding to these insecurities.

\section{Refugees}

As indicated in Table 1, Somalis make up the majority of refugees in the Dadaab refugee camps, but the population also includes some refugees from other African countries (Ethiopia, Eritrea, Sudan, and others) (Fig. 1). The refugee population at the Dadaab camp is far beyond the original intended capacity of 90,000 people.

This large number of refugees puts pressure on both the local community and the available scarce natural resources. On the other hand, the presence of United Nation High Commission for Refugees (UNCHR) and other humanitarian organizations in the region has brought infrastructure developments (boreholes, hospitals, schools, etc.) The local economy has also improved in terms of the availability of essential products and infrastructure services. For instance, Equity Bank has recently opened a branch in Dadaab and is providing full banking services to the community.

Nevertheless, the refugees still live in a limbo (Abdi 2005). They complain that the tents they live in are so tattered that they are exposed to theft and other vices. They also mentioned that girls and women are exposed to sexual and gender-based violence (SGBV) risks due to lack of proper shelter. Besides, the pit latrines in the camps are dilapidated, exposing them to

Table 1 Refugees in DADAAB camp

\begin{tabular}{|c|c|c|c|c|}
\hline \multirow[t]{2}{*}{ Camp } & \multicolumn{2}{|l|}{ Population } & \multicolumn{2}{|c|}{ Country of origin } \\
\hline & Registered & Unregistered & Somalis & Other nationalities \\
\hline & & & $\%$ & $\%$ \\
\hline Hagadera & 138,533 & 805 & 99 & $1^{1}$ \\
\hline Dagahaley & 123,530 & 696 & 95 & $5^{2}$ \\
\hline IFO & 117,215 & 855 & 91.5 & $8.5^{3}$ \\
\hline IFO 2 & 73,020 & 775 & 99.1 & $0.9^{4}$ \\
\hline Kambioos & 12,848 & 551 & 99 & $1^{5}$ \\
\hline Total & 465,146 & 3,682 & & \\
\hline
\end{tabular}

Source: UNHCR (2012) Camp Profiles, Nairobi, Kenya: Author

${ }^{1}$ Ethiopians

${ }^{2}$ Ethiopians, Eritreans, and Sudanese

${ }^{3}$ Ethiopians (7.5 \%); other nationalities ( $1 \%-12$ nationalities in total)

${ }^{4}$ Ethiopians

${ }^{5}$ Ethiopians 
Fig. 1 Kenya-County-Map (History Centre, no date). Retrieved from http://www. herstorycentre.org/our-areas-ofoperation/attachment/kenyacounty-map

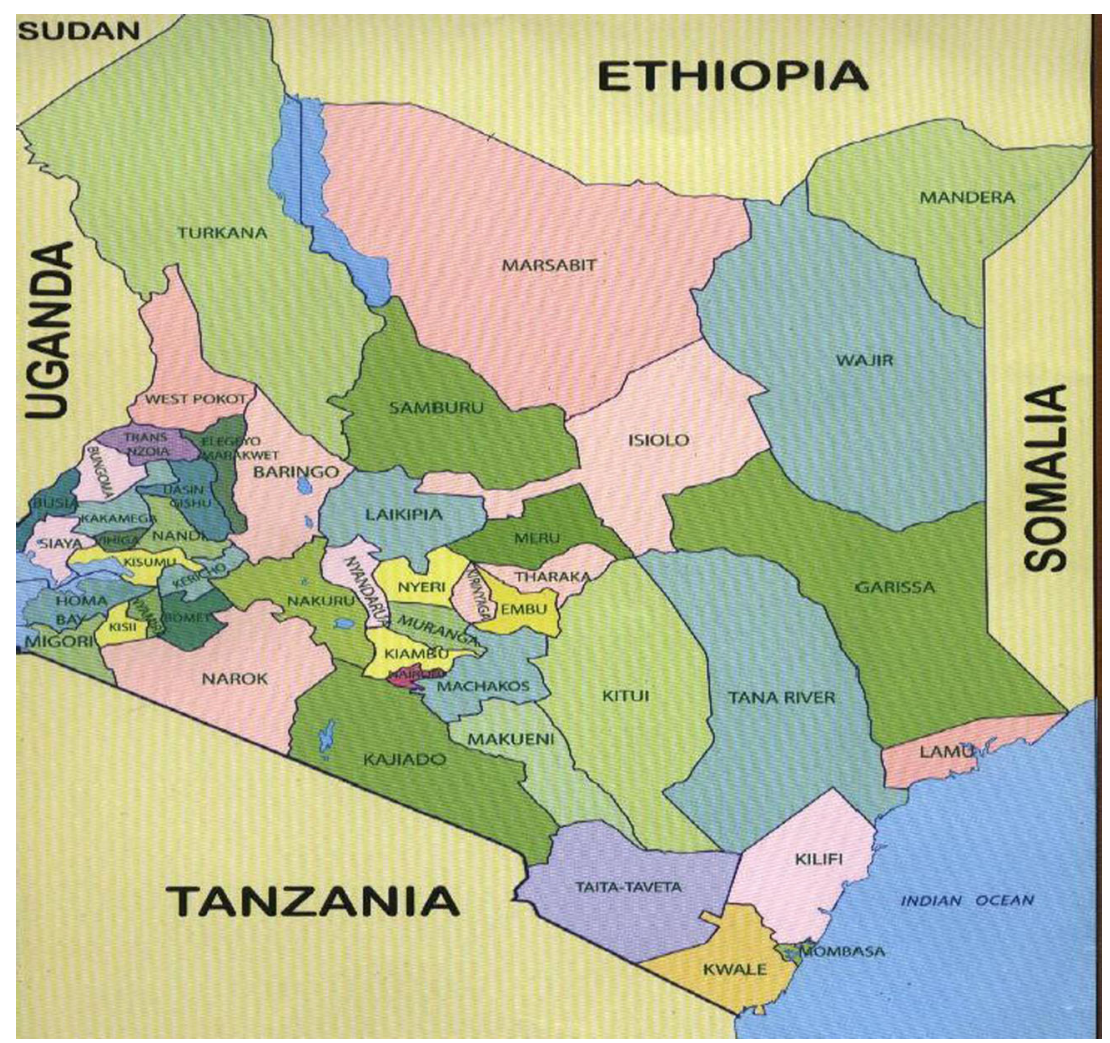

health risks and outbreaks of diseases such as cholera (Kumssa and Jones 2014).

Refugees oftentimes experience insecurity and harassment not only from the host community but also from the national authorities (Abdi 2005). The causes and patterns of conflict in Dadaab are complex and closely intertwined with ethnicity, environmental degradation, competition over scarce resources, and the influx of illicit arms from neighboring countries, particularly from Somalia (Kumssa and Jones 2014).

Dadaab is located in arid and semi-arid regions of Kenya with little natural vegetation. Both refugees and host community residents have cut down trees to build shelters and to use as firewood, a situation that has exacerbated environmental degradation. Women and young girls are often exposed to SGBV whenever they venture out over long distances to collect firewood.

\section{Host Community}

Dadaab refugee camp is located in the arid and semi-arid lands (ASALs) of Kenya. ASALs constitute about $80 \%$ of the country's land mass; host about 10 million people and approximately $70 \%$ of the national livestock herd (Government of Kenya 2006). The area is one of the most underdeveloped regions in the country and suffers from a high level of human insecurity, poverty, and low levels of human development, a situation that is partly a result of a long history of economic marginalization and social exclusion (Kumssa, Jones and Williams 2009). The people who live in this area are mainly pastoralists. The region is generally a net food importer and is a region of Kenya that has a high food insecurity (Fig. 2). In the recent past, most areas in the region experienced drought and famine, mainly due to inadequate rainfall. Inadequate rainfall and severe droughts in these arid and semi-arid lands provoke migrations and exert tremendous pressure on already stressed social and economic systems of this pastoral society (Meier and Bond 2007). Markakis (1997) suggests that this pressure on scarce resources oftentimes leads to violent pastoral conflicts. During a crisis situation, the community will employ a variety of traditional means of conflict resolution and economic or livelihood strategies to cope with the effects of a particular shock, such as a drought (Catley, Burns, Abebe and Suji 2008).

The community's well-being is similarly adversely affected by conflict and drought, and the majority live below the poverty line. This is clearly evidenced by poor infrastructure, inadequate income-generating opportunities, high levels of starvation, malnutrition, etc. Given the fact that animal rearing is the main source of income for host community residents, the competition over and access to natural resources has contributed to conflict among pastoralist communities and the refugees. Local community residents maintain that refugees destroy their environment by cutting trees and damaging the vegetation. This results in local residents confronting refugees when they venture out of the camp in search of firewood and other essentials. The refugees and host community residents conflicts also arise due to the disproportionate humanitarian 
Fig. 2 Major refugee centers in relation to areas of food shortage. (UNHCR/USAID, as cited in Nazret.com, no date). Retrieved from http://nazret.com/blog/ index.php/2011/07/04/starvationreturns-to-the-horn-of-africa

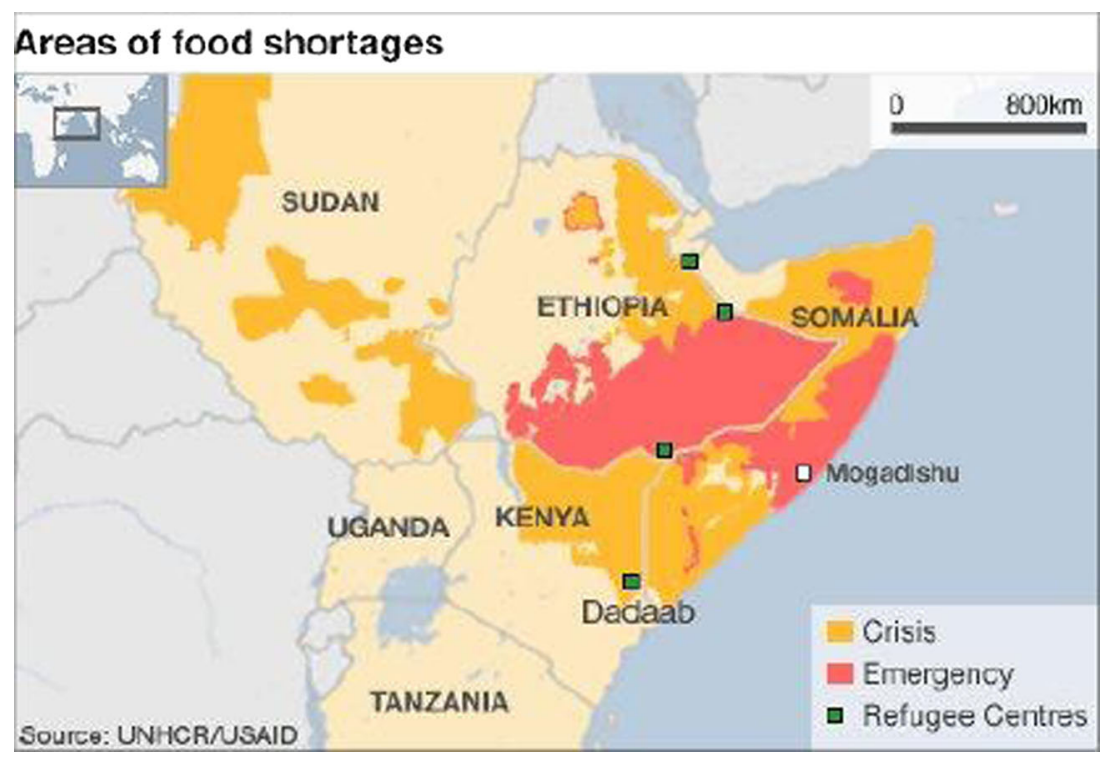

aid provided to each group. In comparison to local residents, the refugees are often perceived to enjoy relatively good nutritional status, receive better health services, and free schooling. Poor infrastructure, inadequate health, low education levels, and inadequate income-generating opportunities are prevalent among local residents. Accessibility to safe drinking water is quite low compared to the national average, and sanitation is severely lacking. Health and education facilities are poor and below the national average. It has been postulated that these dismal socioeconomic and environmental conditions have a direct correlation for the propensity for conflict (Kingsbury et al. 2008).

In addition, the recent influx of refugees to the area has come with its own economic, political, and social consequences. During the field research, residents of the host community confirmed the literature by detailing the various challenges that has developed with the influx of refugees into the area (Kumssa and Jones 2014). They complained of the refugees cutting trees to build shelters and for firewood, thereby depleting the natural resources and exacerbating environmental degradation. They also expressed concerns that criminal gangs within the camps are responsible for the surge in insecurity and violence against women. Despite these concerns, the host community residents actually benefit from the presence of the camp. For example, a study conducted in the camp and surrounding community estimates that the host community get income worth approximately three million (US Dollars) from livestock and milk sales to the refugees (Enghoff, et al. 2010). The same study has also indicated that overall improvements have been implemented in education facilities' access and increase in water for both people and livestock since the development of the refugee camp. The establishment of the camp has also improved other infrastructure facilities (e.g., roads, communication networks, and the availability of financial institutions).

\section{Human Security Issues in the Region}

In several developing countries, development initiatives that focus on economic growth have been successful in increasing income and access to social services. However, the benefits of these initiatives have rarely reached the weakest and most vulnerable groups. Oftentimes, development has also brought about unintended negative consequences such as displacement of people to give room to development activities. For example, large-scale infrastructure projects such as dams, roads, ports, airports, urban clearance initiatives, and the introduction of conservation parks have displaced local residents. Other forces such as conflict and climate change have had negative impacts on vulnerable groups such as refugees, internally displaced people, pastoralists, farmers, poor, and illegal migrants. The underside of development is most noticeable in Northeastern Kenya, an area that has been further devastated by conflict and environmental degradation.

While human security concerns and approaches are critical, initiatives to incorporate a human security orientation in addressing refugee problems and internally displaced people are limited. A human security orientation demands that the needs of the vulnerable such as the refugees should be addressed and integrated into development strategies. Human security approaches identify threats to sustainable development and the factors causing vulnerability of communities. Each community's case is unique in terms of its human security concerns due to geographic, demographic, sociocultural characteristics, and the nature of development institutions. Therefore, when addressing the human security threats to refugees and the host community in Dadaab, 
development strategies should focus on the specific nature of the threats outlined below.

\section{Conflict}

Conflict among the host community residents and with the refugees is a significant challenge. The major conflicts are attributable to resource availability and utilization. The biggest source of conflict arises from competition over grazing land and insufficient water for both animals and humans. Other sources of conflict such as inadequate food, access to health care, low income, and political influence cut across the entire region, fueling conflict between host community residents and refugees. As previously mentioned, the use of natural resources such as cutting down of trees, either for the construction of dwellings or for firewood, has pitted the refugees against the host community residents. Climate change induced drought, water and pasture scarcity has increased conflict between various communities. Several studies have shown that climate change undermines human security by reducing access to and the quality of natural resources that are crucial in sustaining livelihoods. It also increases the risk of violent conflicts (Barnett and Adger 2007).

The trusted conflict resolution institutions or individuals that are normally approached to resolve conflicts include the engagement of the elders/community leaders and the provincial administrator (mainly the chief). Apart from the chief who represents the Government, the conflict resolution mechanisms are tilted towards leaders within the community. Other institutions or individuals involved in conflict resolution include the police, spiritual leaders, community based organizations, and family members.

Disputes between the host community residents and refugees also arise due to differences in the humanitarian treatment provided the various groups. Notwithstanding the difficult conditions in the refugee camps, the refugees are often perceived as relatively well-off due to the good health services, free schooling, and the simple necessities of daily life provided to them by the UNHCR and other humanitarian NGOs (Kumssa and Jones 2014).

Conflicts also erupt between various ethnic groups, clans, and between minority groups and the Somalis in the camp. Minority groups (e.g., Gambellas from Ethiopia) complain of discrimination and cultural intolerance by the Somalis. Gambella girls and women, who are accused of dressing "improperly" and not behaving according to the Islamic tradition, are often stoned when walking to markets. These actions lead to major inter-community conflict. Conflicts are further intensified by gang activities and the absence of alternative livelihoods and peace in the camp. It is therefore important to sensitize the refugees on their common challenges and encourage them to understand other resident's culture, and values, and support each other in the identification and promotion of conflict management strategies. Conflict prevention actors include family members, elders, and peace committees, the police, NGOs, social workers, chiefs, among others. Elders, community leaders and peace committees, and chiefs rank among the top in terms of trusted individuals who support peace efforts. This could be attributed to the governance structures of the Somali society, which emphasizes the role of the clan and community elders in conflict management and prevention.

Shelter

Refugee shelters at the Dadaab camp include the most basic type of structures such as tent or transitional shelters made of wooden poles, iron sheets, and polythene or shelters constructed using interlocking stabilized soil blocks (ISSB) technology. ISSB shelters are more durable and decent compared to other types of shelters. The technology is inexpensive being that most of the materials needed are available on site. However, these types of shelter were recently suspended by the Government of Kenya, which contended that these are permanent structures and should not be built for refugees who are temporary in the country. Shelter among the refugees is one of the major areas of concern. This is understandable given the fact that shelter is essential for survival, personal safety, dignity, and protection from physical assault. It is unfortunate that the government suspended the ISSB shelters since most of the refugees in Dadaab live in makeshift huts or tents that are regularly destroyed by the severe weather and need to be replaced roughly every 6 months.

\section{Water}

Access to safe and clean water is essential to ensure health and safety of refugees. Polluted and nonportable water cause water-borne diseases and affect the health and well-being of the refugees. One of the most common diseases in the camp is diarrhea which is often caused by poor quality drinking and untreated water. The main source of water for both the refugees and the host community residents in Dadaab is from boreholes. This water is untreated. Consequently, it exposes the refugees to all types of diseases. The area does not have springs, rivers, streams, or ponds. Water scarcity is one of the common sources of conflict, especially around shared clan and communal boreholes. During the rainy seasons, the camp is prone to flooding and water-borne diseases due to an unhygienic environment and congestion.

\section{Source of Energy}

The main source of fuel in the area is firewood, which is primarily gathered outside the village and collected mainly by women and children. A few members use charcoal for 
cooking at the household level, while a negligible number uses dung for fuel. In obtaining the fuel, community members are faced with challenges such as that of walking long distances to obtain the fuel, personal security, scarcity of fuel as the population increases, and high prices of fuel, especially for those who have to purchase charcoal or firewood. Women fetching firewood are often raped, making it difficult for them to go out to fetch firewood to cook the food provided by the WFP. To ameliorate this problem, UNHCR in early 1990s introduced a firewood project for the refugees with the objective of

- Reducing sexual-based and gender violence (SBGV) on women and children;

- Providing the firewood as a humanitarian assistance to help cook the food provided; and

- Sustainably managing the firewood harvesting to minimize adverse environmental impacts through a program of managed harvesting zones, monitoring the quality of the harvested wood (GIZ 2011).

According to the same study, the distance from which the firewood is gathered has increased over the past 20 years from $5-10 \mathrm{~km}$ to about $70 \mathrm{~km}$ at present, putting tremendous strain on women and young girls who are tasked with collecting firewood.

\section{Education}

Education is a basic right, one that is vital in restoring hope and dignity to refugees who have been driven from their homes due to conflict and environmental degradation. It helps them to get back on their feet and build a better future. The education levels in the region are low compared to the rest of the country and worse in the refugee camps. The majority of the people in the area only have primary level education, and very few have college level education. Most members of the community take their children to schools in the area. The conditions of the classrooms are appalling. Among the reasons for the low education levels include the nomadic lifestyle, lack of physical facilities, lack of skilled teachers, and a lack of understanding as to the importance of education.

\section{Sustainable Livelihoods and Income}

Business is the most preferred source of income and livelihood in Daadab. Livestock husbandry ranks second, while the provision of skills and agriculture follows in that order. Obviously, agriculture is not popular in the region. The area's social economic and cultural factors could explain why agriculture is not highly ranked compared to other parts of Kenya. The communities in the northeastern part of Kenya are largely nomadic pastoralists who keep camels and goats. The preferences for business as a key source of income could also be attributed to the residents' business acumen and access to markets for livestock, retail shops, clothing, and other forms of trade thriving in the region.

\section{Findings and Recommendations}

Review of available literature, secondary data, and face-toface interviews point to a lack of capacity, both among refugees and host community residents, in creating sustainable and alternative livelihoods. The capacity of host community residents as well as that of refugees to create and sustain their livelihood is necessary for their self-reliance and survival. The findings highlight the systems of access to and control over resources and have resulted in increasing frustration and tension. The local community has become increasingly concerned about the loss of vegetation and forest cover in their area. Not only was fuel wood collection becoming more difficult, but their livelihoods are becoming less secure. This has fueled conflict between the host community residents and refugees.

It is imperative to recognize the importance of integrating humanitarian assistance with development-oriented interventions so as to promote self-reliance and sustainable livelihoods for both refugees and host community residents. These interventions should also include the provision of alternative sources of energy, shelter, improving water and sanitation, quality of education, and entrepreneurial skills. Both refugees and host community residents will require capacity building to engage in productive economic activities aimed at reducing threats encountered while accessing food, shelter, health services, and economic security. Within the overall context of human insecurity, it is important to build the capacity of both communities so as to reduce vulnerability and strengthen their resilience to human security threats such as conflict, environmental degradation, violence, and lack of capacity. The intervention strategy should also focus on capacity building and conflict management so as to empower people through the exchange of information, promotion of knowledge, and developing skills for improved livelihoods and to enable both refugees and local community residents to deal with conflicts in a sustainable manner (Kumssa and Jones 2014).

However, it is important to note that funding is a major constraint in effectively implementing livelihood projects and programs. In this regard, strategic fund-raising activities should be undertaken targeting both traditional donors as well as Middle Eastern Countries. Turkey has a presence in the camps and provides some humanitarian assistance, but fundraising program should also target countries like Saudi Arabia, Kuwait, the Gulf States, and Scandinavian countries.

It is also key to underscore the importance of complementing humanitarian assistance with long-term development projects to help the refugees support themselves by carrying out economic activities that boost self-reliance 
and improve sustainable livelihood. In this regard, while humanitarian NGOs and United Nations (UN) agencies such as UNHCR, World Food Programme (WFP) and others could provide short-term humanitarian support, other organizations such as United Nations Development Programme (UNDP), United Nations Environment Programme (UNEP), and others should also come on board and support the refugees in improving their livelihood and rehabilitating the degraded environment in the Dadaab area. Livelihood creation necessitates the mobilization and coordination of local government, NGOs, UN agencies as well as local community. In this regard, the roles and responsibilities of various organizations- UN agencies, central and local governments, nongovernmental organizations (NGOs), and local communitiesbecome crucial in terms of creating partnerships to integrate humanitarian assistance with long-term development. Capacity building in livelihood creation has to also focus on preparing both refugees and host community residents to overcome factors that hinder or constrain them from effective resource utilization to meet their basic needs. In terms of priority, shelter, peace building, and conflict management and water and sanitation require urgent and immediate attention.

\section{Provision of Shelter}

To address the refugees' poor living conditions, shelter should be a top priority. The UN and other NGOs are doing their best to provide tents, transitional shelters, and interlocking stabilised soil bricks (ISSBs) technology in the construction of refugee shelters. However, as mentioned earlier, ISSB shelters were discontinued in July 2012 by the Government of Kenya, which claimed that that ISSB shelters are not temporary refugee shelters (UNHCR 2013) (Fig. 3). In November 2012, the Government approved the construction of transitional shelters made up of timber frames, plastic sheeting

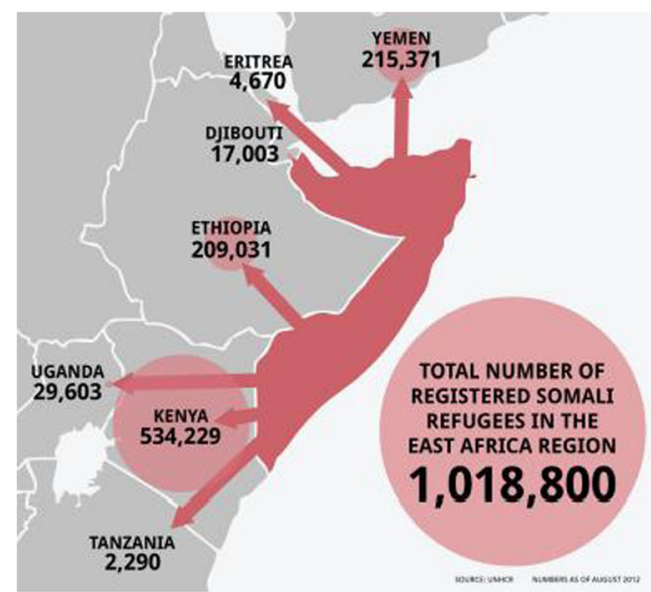

Fig. 3 UNHCR estimates for Somali out-migration as of 2012. (UNHCR as cited in Canadian International Council, no date). Retrieved from www.opencanada.org walls, and iron roof, which are much better and spacious than tents that have a limited life span of about 6 months. In the meantime, negotiations should continue with the Government about other shelter options or the possibility of reintroducing ISSBs. The reintroduction of ISSBs will not only provide quality and decent shelter to the refugees but it will also reduce the cutting of trees for building houses and thereby positively impact on the environment in Dadaab (Fig. 4).

\section{Peace Building Support}

It is important to sensitize both refugees and host community residents on their common challenges and help in the identification and promotion of conflict management strategies. To reduce conflict in the community, there is a need to train peace committee members and local community members on conflict prevention and mitigation measures. Shrinking economic opportunities for the people are both a cause and effect of conflict in Dadaab. Given the fact that the pastoral economy is the main source of income for the host community residents, competition over control and access to natural resources has

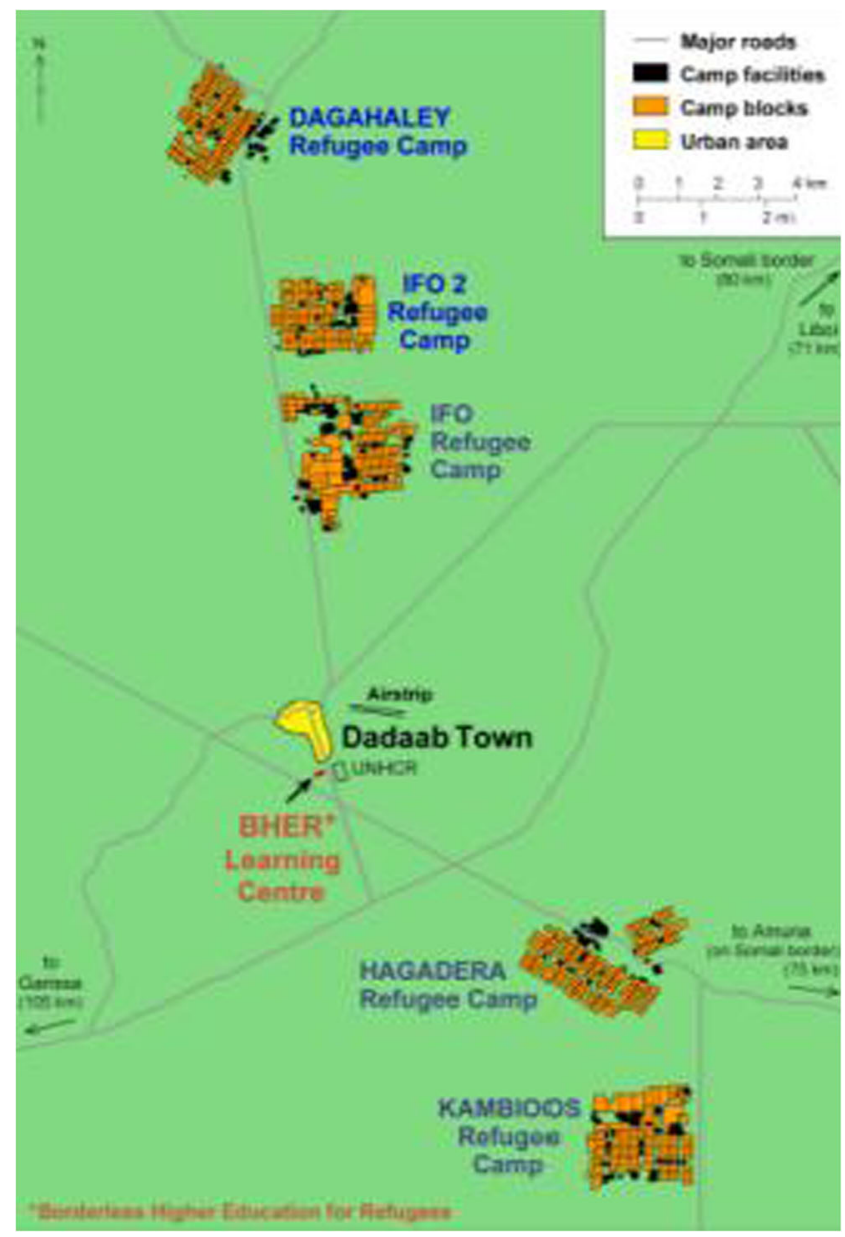

Fig. 4 Refugee camps hosting Somalis. (Cartographic Office, York University, 2012 and Joseph Mensah, as cited in Borderless Education for Refugees. no date). Retrieved from crs.yorku.ca/bher-dadaab-about 
contributed to conflicts among pastoralist communities. Conflicts between host community residents and refugees are also fueled by differences in the humanitarian aid that each group receives. Despite the difficult conditions in the refugee camps, the host community perceives the refugees as enjoying relatively good health services and nutritional status, besides free schooling through UNHCR's and other humanitarian organizations' support. To address these challenges, it is important to design conflict prevention and management capacity-building programs to address the root causes of conflict through the identification and promotion of both sustainable livelihoods and conflict management strategies. It is also important to revive and strengthen traditional conflict management institutions and strategies, as studies in many parts of Africa have proven that traditional institutions can moderate such conflicts (Nordas and Gleditsch 2007). In this process, it is also important to focus on the most marginalized and affected groups such as women, who are often more vulnerable to conflict than men due to their socially and culturally constructed roles and responsibilities.

The capacity building and conflict management program should target the following:

- Members of faith-based organizations;

- Community leaders and elders;

- Peace committee members;

- Chiefs and the local police;

- Youth and women groups;

- Opinion leaders; and

- Local politicians, etc. (Kumssa and Jones 2014)

Conflict and military strife will bring tremendous human and material losses to both refugees and host community residents. The increase in violent conflicts over distribution of resources will hamper social integration and divert attention and resources away from economic development to conflict management. It will also adversely affect the livelihood of the community and impact on the health of both refugees and host community residents.

\section{Environment and Alternative Sources of Energy}

The environment within the Dadaab refugee camps and its surrounding areas has been continuously damaged since the early 1990s. The camps capacity has been surpassed fivefold. This high population aggravates the negative impacts of ecological footprints. Incessant pressure on the environment can overstretch its resilience to an irreversible ecological collapse. Currently, the most commonly acknowledged impacts emanate from the collection of firewood and wood for shelter construction, burning of charcoal both for local consumption and export to Somalia, over-stocking of domestic livestock, over abstraction of ground water, lack of a proper solid waste management system, and sanitation.

Both host community residents and refugees engage in cutting down trees for firewood and shelter construction, depleting the natural resource and exacerbating environmental degradation. Environmentally friendly projects should be initiated to positively contribute to environmental protection as well as address the challenges of energy among host community residents and refugees. Refugees and host community residents should be provided with alternative sources of energy such as solar and energy-saving stoves. Many humanitarian organizations are providing energy-saving stoves, but they are far from meeting the growing need. Fuel-efficient stoves and solar energy will reduce the vulnerability and exposure of women and girls to risks emanating from long distance travel in search of firewood. It will also mitigate the environmental degradation of the area and thereby reduce the potential of conflict between refugees and host community residents.

\section{Water and Sanitation}

To improve water accessibility, boreholes should be rehabilitated in selected areas in the region. This should go hand in hand with trainings on hygiene and sanitation. The problem of water is especially acute among the newly arrived refugees, who have settled on the outskirts of the camps. These refugees have to travel long distances to access water, sometimes traveling for up to $3 \mathrm{~km}$ to the nearest water point. The water situation for host community residents is similar to those of the refugees (Lutheran World Federation 2011).

\section{Improving Quality Education}

It is important to improve the quality of education by upgrading the skills and knowledge of teachers. Schools should be provided with the necessary teaching materials. International organizations have done a commendable job in this regard, but the demand for classrooms and quality education is still very high. In 2012, the first high-level institution in Kenya, Dadaab Campus of Kenyatta University, was set up in Daddab to cater for Somali refugees and host community residents. The curriculum includes diploma, undergraduate, and post graduate courses in public policy, peace and conflict studies, commerce, and education, which are open to refugees, students from the local community, and the staff of humanitarian agencies (NTA News Africa 2012). This initiative is a step in the right direction and will improve the education level of both the refugees and the members of the host community who had been deprived of higher education opportunities in the past. 
Improving the Livelihoods of Women and the Youth

Starting small-scale businesses will reduce youth unemployment by engaging them in productive economic activities. Skills in business entrepreneurship should be taught. These skills should include tailoring, computer training, and the management of Internet cafés. This is important because skills development and education are critical in self-empowerment and increase the prospects of employment, higher wages, and social mobility, besides improving the lives of the youth and women (Barnett and Adger 2007). Incomegenerating activities among women may focus on cloth-making, hairdressing skills, tailoring and weaving skills, tye and dye training, water kiosk, market stalls, and poultry farming (Kumssa and Jones, 2014).

\section{Durable Solutions}

According to UNHCR, there are three practical solutions to the refugee crisis: 1) integration into the host society, 2) resettlement in a third country, or 3 ) repatriation to the country of origin. Integration into the local society could be a challenge due to sensitivity to land issues, expressed through resentment by the landless local communities (Abdi 2005). While integration into the Kenyan society seems difficult, repatriation is not an easy alternative. In the meantime, on November 10, 2013, the Governments of Kenya, Somalia, and UNHCR signed a repatriation agreement to return the more than one million Somali refugees in Kenya back to their country through voluntary basis and established international legal framework. This plan of repatriating Somali refugees is triggered by the recent terrorist attack in Kenya and the security concerns blamed on the infiltration of the refugee camps by suspected Al Shebaba terrorist groups or their sympathizers (Business 2013). The UNHCR reiterated that the agreement signed would still require continued protection of Somali refugees in Kenya and recognized the need for permanent solutions to their plight.

In spite of many claims that normalcy has returned to Somali, the political situation remains precarious, and AlShabaab is still a force to reckon with. For example, according to International New York Times, on November 19, 2013, 28 people were killed and scores wounded by Al-Shabaab when they attacked a police station in a town north of Mogadisho (International New York 2013).

Also, many of the Somali refugees have no living close family members across the border, and those who had properties that provided them with a means of livelihood have had their property either destroyed or violently appropriated (Global 2012). Without financial support and capacity building programs to facilitate their reintegration into their society, it would be very difficult to have a smooth and successful repatriation program. Moreover, the continuing insecurity and the lack of opportunities across the border means that voluntary compliance is highly unlikely (Global 2012). Considering the challenges faced with integration and repatriation, the third viable option is the resettlement of the refugees in a third country. Many developed countries such as the United States, Canada, Australia, Norway and others have allowed refugees to settle in their countries. This option should be vigorously pursued and expanded to accommodate more refugees, especially those in limbo at the Dadaab refugee camp. Given the rise in right-wing groups in developed countries, and the economic and financial crisis that the West is faced, this option also present challenges.

\section{Conclusion}

Both refugees and host community residents face several economic, social. and political challenges. The two populations share a common language, culture, and religion, and in some cases clan and sub-clan identities (Enghoff et al. 2010). International humanitarian organizations have done a commendable job to address the needs of both refugees and host community residents, but tremendous gaps remain. The needs of these communities require ongoing attention and effective interventions. It will be practically impossible to address all community needs, but certain priority areas previously discussed require urgent attention. Interventions should be designed and implemented to utilize a more balanced approach that includes humanitarian assistance with long-term sustainable development strategies. Within the overall context of human security, the strategy should aim at reducing vulnerability and increasing the human security of communities affected by conflict through capacity building in conflict prevention and management skills along with identification and promotion of sustainable livelihood strategies. Through identification and promotion of both sustainable livelihood and conflict management policies, the strategy should address the three pillars of human security, namely freedom from fear (conflict), freedom from want (creation of sustainable livelihoods), and freedom to live in dignity.

The situation of refugees varies from country to county due to the differences in the causes and patterns of conflict and migration, etc. It is to be expected that some sources of conflict are purely internal — ethnic or religious - and some reflect the dynamics of the regional and global economy while others are linked to bad governance and environmental degradation.

The findings of this study have implications for all refugees because it emphasizes the rationale and importance of designing and implementing projects that would complement humanitarian assistance with long-term development projects and capacity-building programs to help the refugees support themselves by carrying out economic activities that boost their self-reliance and improve their sustainable livelihood. The 
skills and knowledge the refugees have acquired, through capacity building and livelihood programs, will enhance their resilience and innovative capacity and help them to smoothly integrate into the society when they return to their home or resettle in another country.

\section{References}

Abdi, A. M. (2005). In limbo: dependency, insecurity, and identity amongst Somali refugees in Dadaab Camps. Refuge, 22, 6-14.

Barnett, J., \& Adger, W. N. (2007). Climate change, human security and violent conflict. Political Geography, 26, 639-655.

Borderless Education for Refugees (no date). Dadaab Camps. Retrieved from http://crs.yorku.ca/bher-dadaab-about

Business Daily, (2013). Kenya, Somalia Agree on Repatriation Plan. Accessed on April 29, 2013 from www.businessdailyafrica.com.

Campbell, E., Crisp, J., \& Kiragu, E. (2011). Navigating Nairobi: a review of the implementation of UNHCR's urban refugee policy in Kenya's capital city. Geneva: UNHCR.

Catley, A., Burns, J., Abebe, D., \& Suji, O. (2008). Participatory impact assessment: a guide for practitioners. Boston, MA: Tufts University.

Daily Nation. (2012). Refugees told to get out of town. Wednesday, December 19, 2012.

Enghoff, M., Hansen, B., Umar, A., Gildestad, B., Owen, M., \& Obara, A. (2010). In Search of Protection and Livelihoods: Socio-economic and Environmental Impacts of Dadaab Refugee Camps on Host Communities. http://kenya.um.dk/en/ /media/Kenya/Documents/ Final\%20Report30092010.ashx

GIZ (2011). The GIZ Dadaab household energy project. Accessed on November 5, 2013. https://energypedia.info/images/5/57/GIZ Dadaab.pdf

Global South (2012). The world's largest refugee camp: what is the future for Dadaab? Accessed on April 24, 2012. http:/gsdmagazine.org/2012/12/ 26/the-worlds-largest-refugee-camp-what-is-the-future-for-dadaab/
Government of Kenya. (2006). National policy for the sustainable development of arid and semi-arid lands of Kenya. Nairobi: Office of the President.

Hasegawa, Y. (2007). Is a human security approach possible? Compatibility between the strategies of protection and empowerment. J Refug Stud, 20, 1-20.

Human Rights Watch (2013). Kenya do not force 55,000 into camps. Accessed on April 20, 2013. http://www.hrw.org/news/2013/01/21/ kenya-don-t-force-55000-refugees-camps.

International New York Times (2013). Dozens die in attack on police station in Somali. Wednesday, November 20, 2013.

Kingsbury, D., McKay, J., Hunt, J., McGillivaray, M., \& Clarke, M. (2008). International development: issues and challenges. New York: Palgrave Macmillan.

Kumssa, A., \& Jones, J. F. (2014). Human security issues of Somali Refugees and the host community in Northeastern Kenya. Journal of Immigrant \& Refugee Studies 12(1), 27-46. doi:10.1080/ 15562948.2013.810797

Kumssa, A., Jones, J. F., \& Williams, J. H. (2009). Conflict and human security in the North Rift and North Eastern Kenya. Int J Soc Econ, 36, 1008-1020.

Loescher, G., \& Milner, J. (2005). The long road home: protracted refugee situations in Africa. Survival, 47, 153-174.

Lutheran World Federation (2011). Kenya-3rd update situation in Dadaab, 17th July 2011. Accessed on April 24, 2013. http:// lwfworldservice.wordpress.com/2011/07/18/kenya-3rd-updatesituation-in-dadaab-17th-july-2011/

Markakis, J. (1997). Resource conflict in the Horn of Africa. London: Sage.

Meier, P., \& Bond, D. (2007). Environmental influences on pastoral conflict in the Horn of Africa. Political Geography, 26, 716-735.

Menkaus, K. (2012). After the Kenyan intervention in Somalia. Accessed on April 20, 2013. http://www.enoughproject.org/files/ MenkhausKenyaninterventionSomalia.pdf

Nordas, R., \& Gleditsch, N. P. (2007). Climate change and conflict. Political Geography, 26, 627-638.

NTA News Africa. (2012). Accessed on April 21, 2013. http://www. newstimeafrica.com/archives $/ 28688$

UNHCR (2013). Kenya (Dadaab)-2011-Famine/conflict. Accessed on April 22, 2013. http://www.sheltercasestudies.org/ shelterprojects2011-2012/A15-Kenya-Dadaab-2011.pdf 